\title{
PBF ADMINISTRATIVE CONTROL OF CONSTRUCTION COMPONENT TESTS
}

\section{MiASTER}

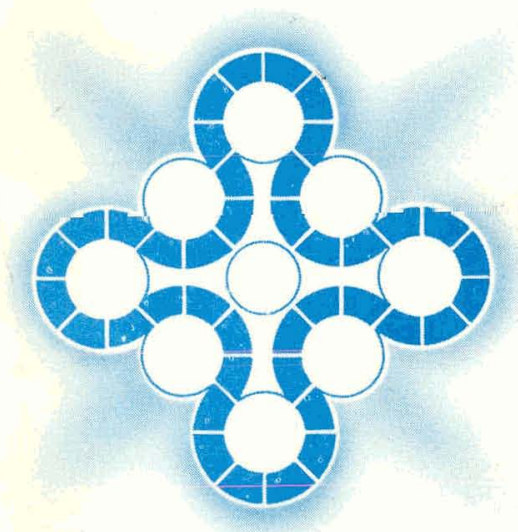

\section{Aerojet nuclear Company}

NATIONAL REACTOR TESTING STATION Idaho Falls, Idaho - 83401

\author{
Date Published - July 1972 \\ PREPARED FOR THE \\ U. S. ATOMIC ENERGY COMMISSION
}

IDAHO OPERATIONS OFFICE UNDER CONTRACT AT(10-1)-1375 


\section{DISCLAIMER}

This report was prepared as an account of work sponsored by an agency of the United States Government. Neither the United States Government nor any agency Thereof, nor any of their employees, makes any warranty, express or implied, or assumes any legal liability or responsibility for the accuracy, completeness, or usefulness of any information, apparatus, product, or process disclosed, or represents that its use would not infringe privately owned rights. Reference herein to any specific commercial product, process, or service by trade name, trademark, manufacturer, or otherwise does not necessarily constitute or imply its endorsement, recommendation, or favoring by the United States Government or any agency thereof. The views and opinions of authors expressed herein do not necessarily state or reflect those of the United States Government or any agency thereof. 


\section{DISCLAIMER}

Portions of this document may be illegible in electronic image products. Images are produced from the best available original document. 


\section{LEGAL NOTICE}

This report was prepared as an account of work sponsored by the United States Government. Neither the United States nor the United States Atomic Energy Commission, nor any of their employees, nor any of their contractors, subcontractors, or their employees, makes any warranty, express or implied, or assumes any legal liability or responsibility for the accuracy, completeness or usefulness of any information, apparatus, product or process disclosed, or represents that its use would not infringe privately owned rights. 
PBF

ADMINISTRATIVE CONTROL

OF

CONSTRUCTION COMPONENT TESTS

\section{NOTICE}

This -report was prepared as an accollnt of work sponsored by the United States Government. Neither the United States nor the United States Atomic Energy Commission, nor any of their employees, nor any of their contractors, subcontractors, or their employees, makes any warranty, express or implied, or assumes any legal liability or responsibility for the accuracy, completeness or usefulness of any information, apparatus, product or process disclosed, or represents that its use would not infringe privately owned rights.

\section{AEROJET NUCLEAR COMPANY}

Date Published - July 1972

PREPARED FOR THE U. S. ATOMIC ENERGY COMMISSION

IDAHO OPERATIONS OFFICE

UNDER CONTRACT NO. AT (10-1)-1375 
$\therefore$

BF

ADMINISTRATIVE CONTROL

CONSTRUCTION COMPONENT TESTS

APPROVAL PAGE


$$
\frac{6-14-72}{\text { Date }}
$$

Approved By:
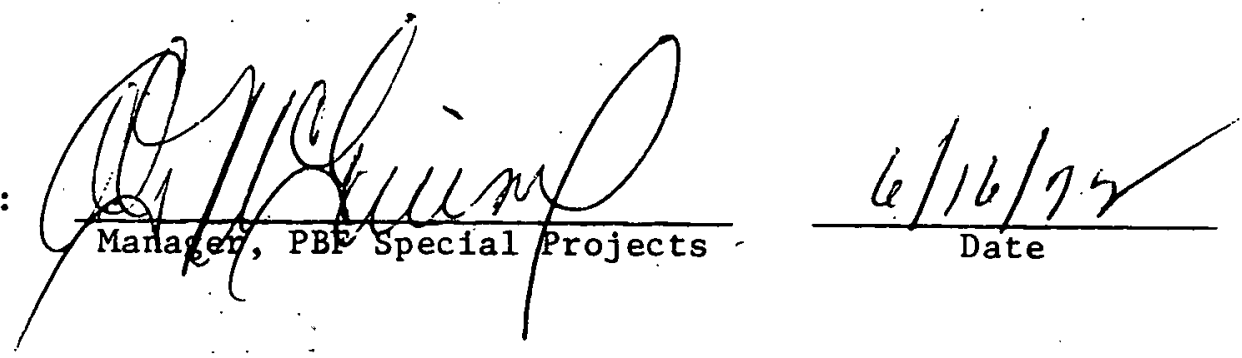

Approved By:


$\dddot{i i}$ 
ABSTRACT

This document presents the mechanisms for the generation and administrative control of construction component tests for PBF. Interface relationship and required approvals are delineated in the זexז . 
A. PURPOSE AND SCOPE -

B. REFERENCES -

C. ORGANIZATIONAL RESPONSIBILITIES CC TEST OPERATIONS FLOW SHEET-FIGURE 1 ------ 5

EXHIBIT A FORM C-100 - 6

EXHIBIT B

EXHIBIT C - 9

EXHIBIT D - 14

EXHIBIT E FORM C-101 - 15

EXHIBIT F FORM C-101a - 16

EXHIBIT G FORM C-102 17

EXHIBIT H FORM C-103

EXHIBIT J FORM C-104

EXHIBIT K FORM C-105 - 20 


\section{$\mathrm{PBF}$ \\ ADMINISTRATIVE CONTROL \\ OF \\ CONSTRUCTION COMPONENT TEST}

A. PURPOSE AND SCOPE

The purpose of Construction Component (CC) testing is to provide the Construction Contractor the opportunity to demonstrate that components and subsystems are correctly installed in accordance with approved drawings and specifications and in accordance with vendor instructions, and are ready to operate.

Scope of the tests is to verify that components are correctly installed and that no failure or damage occurred during installation. Functional testing is not normally included although there may be some exceptions.

B. REFERENCES

1. ANCR-1076, PBF System Operation Test Plan (Operation Phase), R. E. Heffner, (to be published).

C. ORGANIZATIONAL RESPONSIBILITIES

Two companies are involved in writing and accomplishing the CC tests. The tests will be conducted by The Construction Contractor to specifications set forth in the test documentations prepared by Aerojet Nuclear Company. Title III inspection will be performed by ANC R\&QA unless specifically designated by them to other ANC organizations for leve1 II and level III systems.

The responsibilities of each company and interfacing between companies are described below. Referring to Figure 1:

1. ANC Issues First Draft of Test Specifications

2. ANC Reviews Draft and Redrafts

On completion of the test specification by ANC, the PBF Special Projects Branch distributes the document for review to Design Engineering, Quality Assurance and the Project Engineer, and Shift Operations. The comments are resolved by the Special Projects Branch.

3. ANC Approves Specification

The resolved test specification is approved by ANC Shift Operations Manager,. Special Projects Manager, and Reliability and Quality Assurance Representative. 
4. Spectal Profects Issues Test Specification to Title III Representative

PBF Special Projects transmits the CC Test Specification to

ANC Title III Representative for preparation of the test data sheets.

5. Title III Representative Issues Test Data Sheets

Title III Representative issues test data sheets to PBF Special

Projects for review.

6. Special Projects Reviews and Approves Test Data' Sheets

The Test Data Sheets are reviewed and approved by the Cognizant Project Engineer and the Manager, PBF Special Projects.

7. Special Projects Issues Test Data Sheets and Specifications to Construction Contractor, ANC and AEC-ID

8. Construction Contractor Requests CC Test (or Retest)

When the installation of a component is completed, the Construction Contractor will request the CC test by completing form CC-100 "Request for CC Test" and transmitting it to ANC approximately one week prior to the test. A sample of this form is shown

in Exhibit $A$.

9. Title III Inspection and Special Projects Appoint Test Engineers and Inspectors

PBF Special. Projects will appoint test engineers and Title III Inspection will appoint inspectors. Special Projects may waive witnessing of test by the test engineer.

10. Conduct CC Test Readiness Review Meeting

ANC will conduct a CC test readiness review meeting as outlined in Exhibit $B$.

11. Construction Contractor Conducts Test or Retest Under Direction. of ANC

The tests will be supervised by the Construction Contractor. Test Engineers. The Construction Contractor will be responsible for assuring that all test operation preparations have been made. If temporary utility hookups (electricity, water, air, etc.) are utilized, the tag prociedure of Exhibit $C$ is to be followed. Data sha11 be recorded by the Title III Inspector. Any changes or variances to the CC Test Specification or Test Data Sheets shall be resolved as specifled in Exhibit D.

\section{Rejected Test: Red Tag \& Note Deficiencies}

A test is either accepted or rejected. If a test is rejected, the component is red-tagged per Exhibit $C$ and the deficiencies are noted on form C-101, "Exceptions to CC Test" (Exhibit.E). These exceptions are defined as deviations from drawings and design specifications. 
13. Recommend Method of Correction to ANC Resident Engineer

The T1tle III Inspector and ANC Test Englneer recommend the method of correction. Th1s is formulated by Title I[I. Inspection and the Cognizant Profect Englneer and written by ANC to the ANC Resident Engineer on form C-101.

14. ANC Resident Engineer Directs Construction Contractor to Correct Deficiencies

The ANC Resident Engineer will review the deficiencies for validity and evaluate the recommendations for corrertions or repairs. He will then prepare form C-10la, "Deficiency Action Request" (Exhibit F) for transmittal to the Construction Contractor. Retests are made per the CC test specification.

15. Construction Contractor Corrects Deficiencies

The Construction Contractor corrects the deficiencies and requests retest. If the retest is acceptable, the Construction Contractor countersigns form $\mathrm{C}-10 \mathrm{la}$ and forwards to Title III and PBF Special Projects.

16. Acceptable Test: Green Tag

If a test is acceptable, the component is green-tagged per Exhibit $C$ and the completed Test Data Record Sheets are forwarded to ANC Special Projects for approval, accompanied by form C-102 (Exhibit G).

\section{ANC Approve Tests}

Signatures on form $\mathrm{C}-102$ will indicate formal accevtance of . the test by ANC Special Projects will return the approved form C-102 to Title III Inspection for distribution.

18. Title III Inspection Distributes Test Results

Title III Inspection will package the final copy of the approved CC Test Specification, the approved Test Data Record Sheets, Exceptions to the CC Test (form C-101), Corrective Action Request (form C-101a), and the signed off form $\mathrm{C}-102$, and make the following distributions:




19. Transfer Construction Component to ANC

Prior to the System Operation (SO) test, the Construction Contractor will transfer the Construction Component to the Aerojet Nuclear Company in accordance with ANCR-1026, PRF Systems Operation Test Plan (Operation Phase), R. E. Heffner, June 1972 .

20. Suggested Improvements

Recommended changes to the hardware or instrumentation which involve design changes shall be listed on form $\mathrm{C}-103$, "Recommended Improvement List" (Exhibit H) and transmitted to the addressee. This form thus processed is not a. part of the CC test data package.

21. Manager Shift Operations For Future Action

The Manager, Shift Operations will consider the recommendation of form $\mathrm{C}-103$ and will make changes in the future if he concurs.

22. So. Test Waiver

When the so test requirements have been included as a part of the CC test, an so test waiver, Exhibit K, form C-105, signed by the PBF Special Profects Manager and Program Manager, is attached and made a part of the data sheets of the CC test.

23. System Transfer to ANC

Those systems with so test walvers may be transferred to ANC upon successful completion of the related CC test according to procedures in ANCR-1026, PBF Systems Operation Test Plan (Operation Phase), R. E. Heffner, June 1972. 

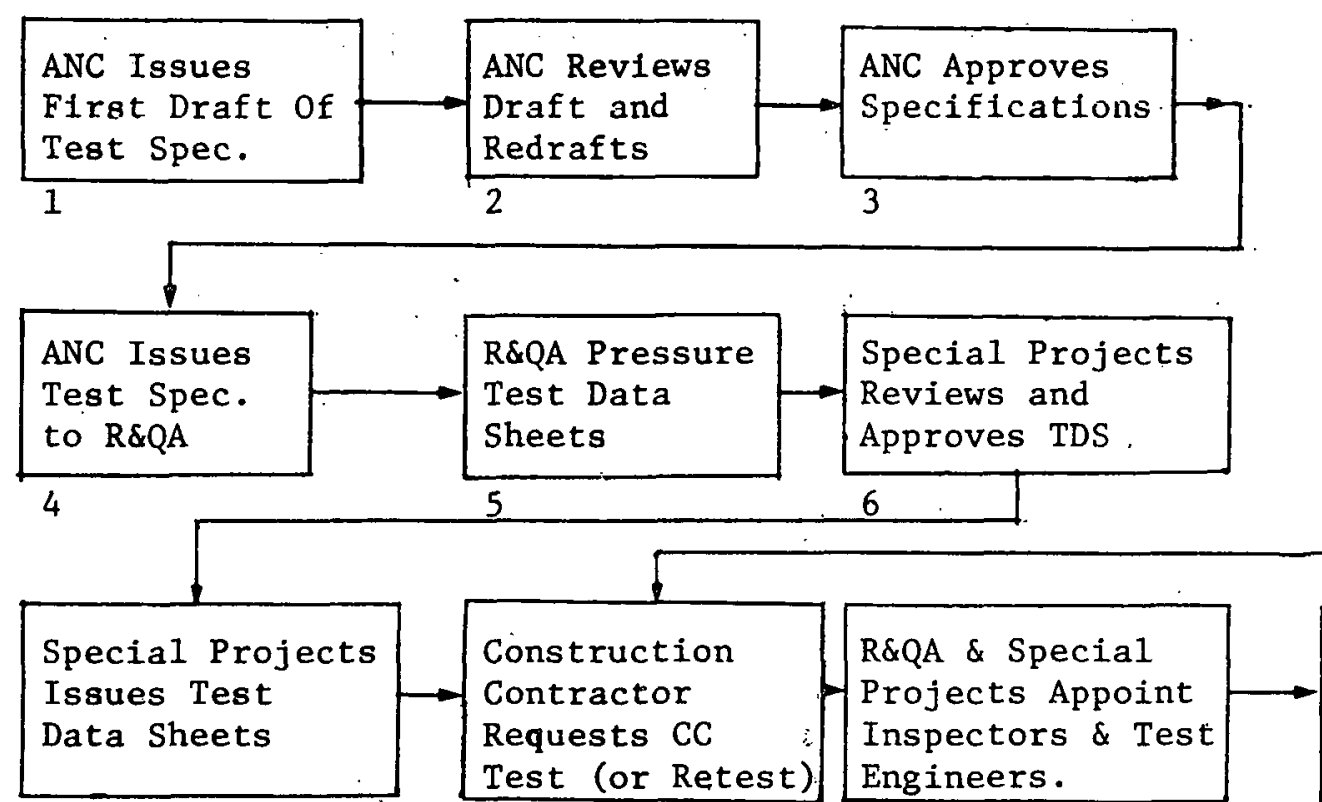

ANC Conduct CC

Test Readiness

Review Meeting

Test (or Retest) Engineers.

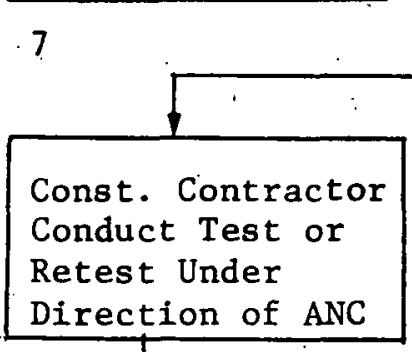

11

8

9

10

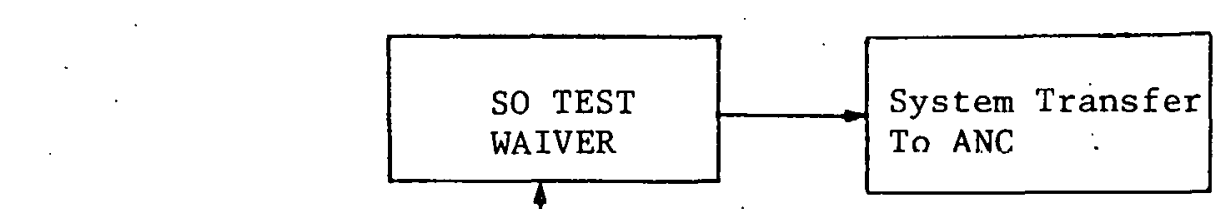

23

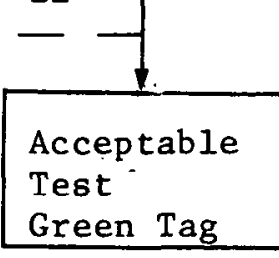

16

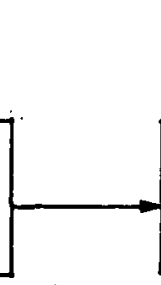

17

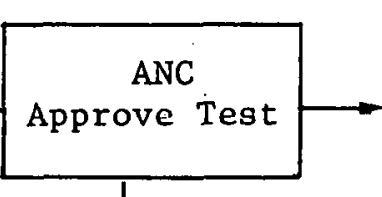

22

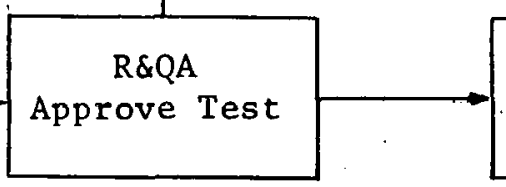

18
Const. Contractor Transfer CC to ANC (Interium)

19



12

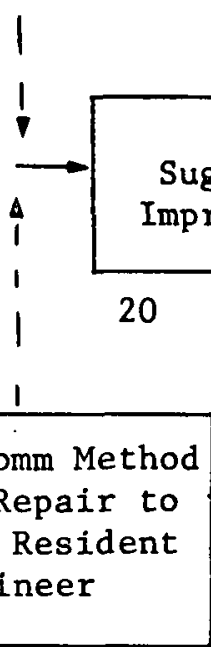

13

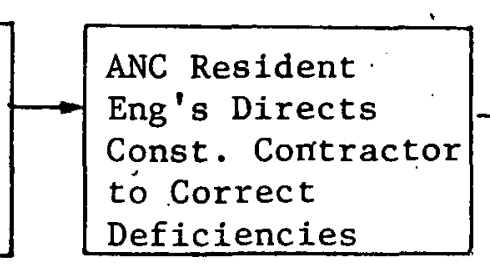

14
Const. Contractor Corrects Deficiencies

Manager Shife

Future Action

21

CC TEST OPERATIONS FLOW SHEET

Figure 1 


\section{Aerojet nuclear Company}

Interoffice Correspondence

PBF P.0. NO.

REQUEST FOR CC TEST NO.

ITEM AND/OR EQUIPMENT NO.

Date

K. C. Ralph

A. G. McGutre

We have completed the installation of to a suf-

ficient degree to permit its CC testing. Please be prepared to witness the test for compliance with applicable specifications.

Date and time of Readiness Review Meeting

Location

Requested By:

-Construction Contractor

Please sign and return one(1) copy of this transmittal designating your inspector or engineer.

$R \& Q A$ Inspector

ANC Test Engineer

Acknowledged By

Date

Distribution:

PBF Program Division, ID

W. E. Durkee

CR.-E.-Hef $\overline{\text { ner }}$

K. C. Relph

R. P. M. Gildersleeve

B. K. Pope

R. E. Heffner ( $f 1 l e$ )

File: $01 \mathrm{A02}$ 


\section{CONSTRUCTION COMPONENT TEST}

READINESS REVIEW MEET ING

\section{PURPOSE}

The purpose of the Readiness Review Meeting is to assure that: (a) equipment, materials, and services are available and adequately prepared for the CC test and (b) proper personnel arrangement have been made and each individual understands his duties. Deficiencies will be identified and the responsibilities for correction will:be specifled.

II. DISCUSSION

Attendance will be expected from the following personnel:

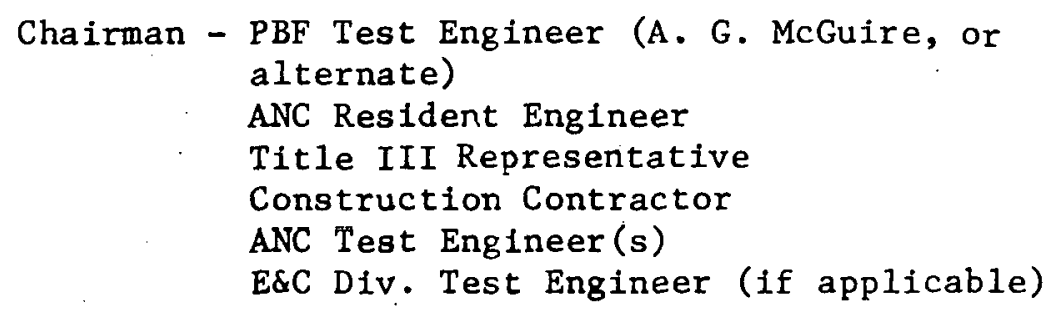

Areas of discussion during the review meeting will include, but not necessarily limited to, the following:
(a) Test engineers and inspectors assignments
(b) Completeness of test specification and test data sheets
(c) Prerequisite completion
(d) Calibration of gauges and instruments
(e) Availability of tooling and test equipment
(f) Availability of temporary utilities.

Action items resulting from the review shall be" noted. The responsibility for accomplishing the action items will be established and completion dates will be set.

Minutes of the meeting will be kept and distributed as determined by the Manager of Speclal Projects with the following as a minimum:

Attendees

PBF-ID Standard Distribution

Construction Contractor (5)

$\mathrm{R} \& \mathrm{QA}$ (3)

Planning and Documentation File (1)

F1le: 01A02 
III. TIME AND PLACE OF MEETING

The review meeting w111 be scheduled at least three days prior to the CC test. The meeting room will be at the PBF construction site. If all test preparations have been made to the satisfaction of the Chalrman, the readiness review meeting may be walved at his discretion. 


\section{TAGGING PROCEDURE}

I

$\underline{\text { PURPOSE }}$

The purpose of this tagging procedure is to provide a uniform guide in applying tags to system components. Its intent is to assure that the status of tested items is visually identifiable in the field.

There are three categories of tags, each colored differently. Orange denotes a temporary facility hookup, or some other incomplete connection, used during a test: Red denotes the 1 tem has falled to pass in some way. Green signifies the item has passed its CC test. These tags are ANC property and for ANC's benefit, and will be prepared and attached by the ANC inspector. In the case of red and orange tags (which require corrective effort), inventory control will be by the ANC Resident Engineer, who will issue the tags and keep a working record of attachment and removal. Green tags require no inventory control. No tags are to be removed by anyone except the authorized ANC representative defined on the card.

\section{A. Temporary Facility (Incomplete Connection) Tag (Orange)}

This tag is to be used whenever a temporary facility is used for a test, or whenever some connection is incomplete and will require proper connection before acceptance of a System Operation Test. A temporary facility or an incomplete connection must have the prior approval of those conducting and approving the test. For example: If temporary air is used during a test, the air to be used and the connection point must receive approval before the test begins. An orange tag is to be placed at the connection, (or as close by as practical so as to be conspicuous to an observer). The intent is to furnish a visual reminder that a system is not fully complete.

Orange tags used during CC tests may remain on items (if necessary) at the time of signing approval form C-102. So tests may start with orange tags in the system, but permanent, approved connections must be made before final approval and acceptance can occur. A record of tested and approved permanent connections must be submitted to the Manager, Special Projects on form C-104 (Exhibit J).

B. CC or SO Test Failure Tag. (RED)

This tag, denoting any type of fallure, which makes the test unacceptable until corrected, is to be placed in a conspicuous location on the item(s) involved. A short description of the nature of the deficlency must be written on the tag. Title III Inspection and the PBF Test Engineer both sign for CC test failure, but only Title III Inspector need sign red tags for so test deficiencies. Failed items are also to listed on form $\mathrm{C}-101$, 
Corrective Action Request. The latter is used by the Construction Contractor as the official guide to performing repairs.

\section{CC Test Approval Tag}

The green "approval" tag will be used to denote that the item, or valve group, or plping section (or any other appropriate grouping) as satisfactorily passed its CC test. Green tags identify by data on them, exactly what is encompassed by their approval. It may be a single item or reasonable accumulation of items (such as a valve group). It indicates the identified items have been inspected or tested according to a referenced CC test and satisfactorily meet requirements. Green tags must be signed by the Construction Contractor (signifying release for further testing), by Title III Inspection (approval of test), and by the PBF Test Engineer. These tags should remain in place at least unt1l the satisfactory conclusion of so testing of the system.

\section{LIMITATIONS}

The use of these tags is mandatory under direction of ANC Management. Their intent as visual evidence of test status, is not to be compromised by failure to apply them. They are to be used as intended, in order that fleld inspections by management can quickly determine failed items and other work remaining to be done. 


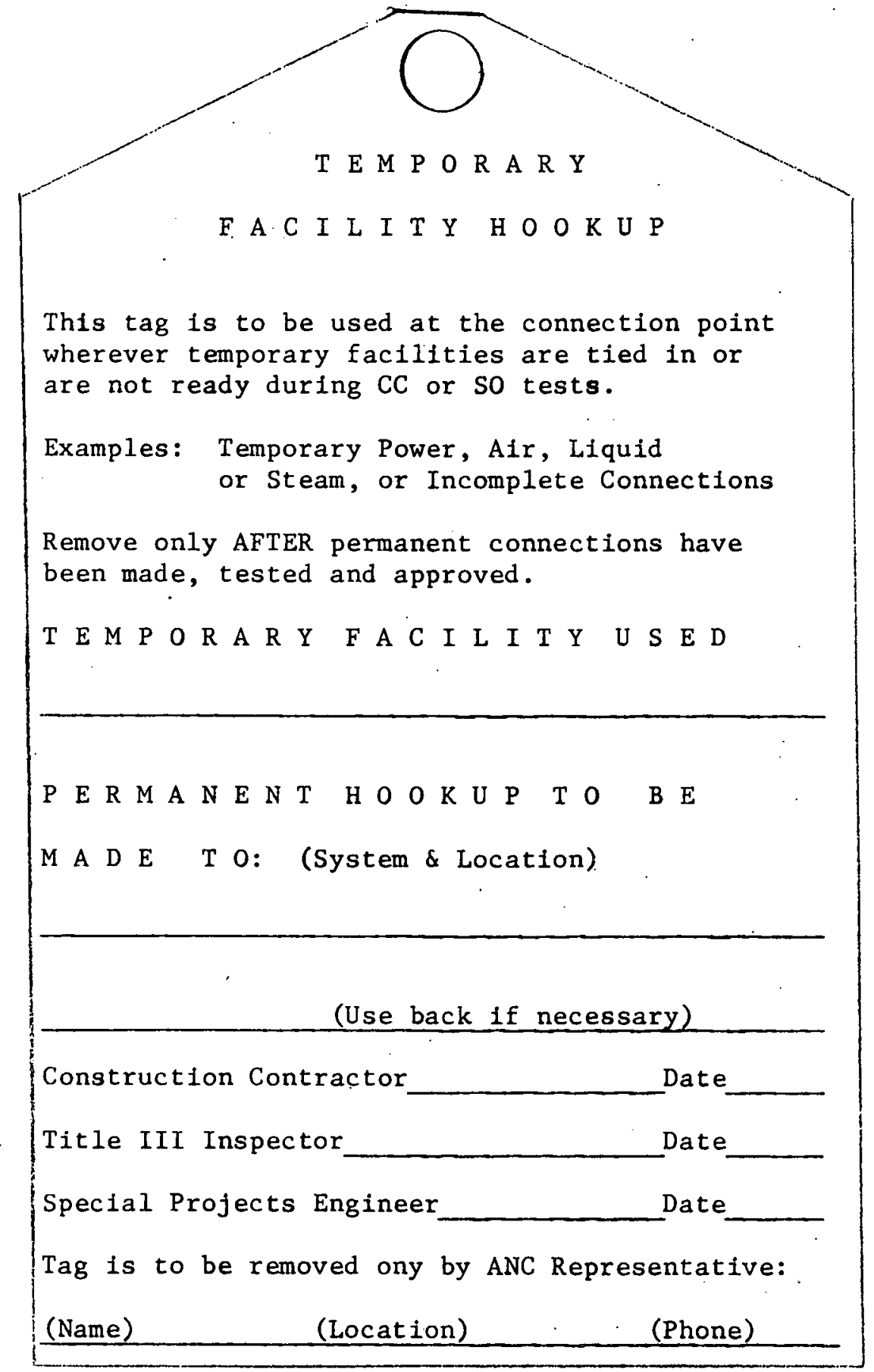

Explanation

Removal limitations

Description for guidance when permanent connections are to be made.
This is an ANC tag. Others should not remove it. 


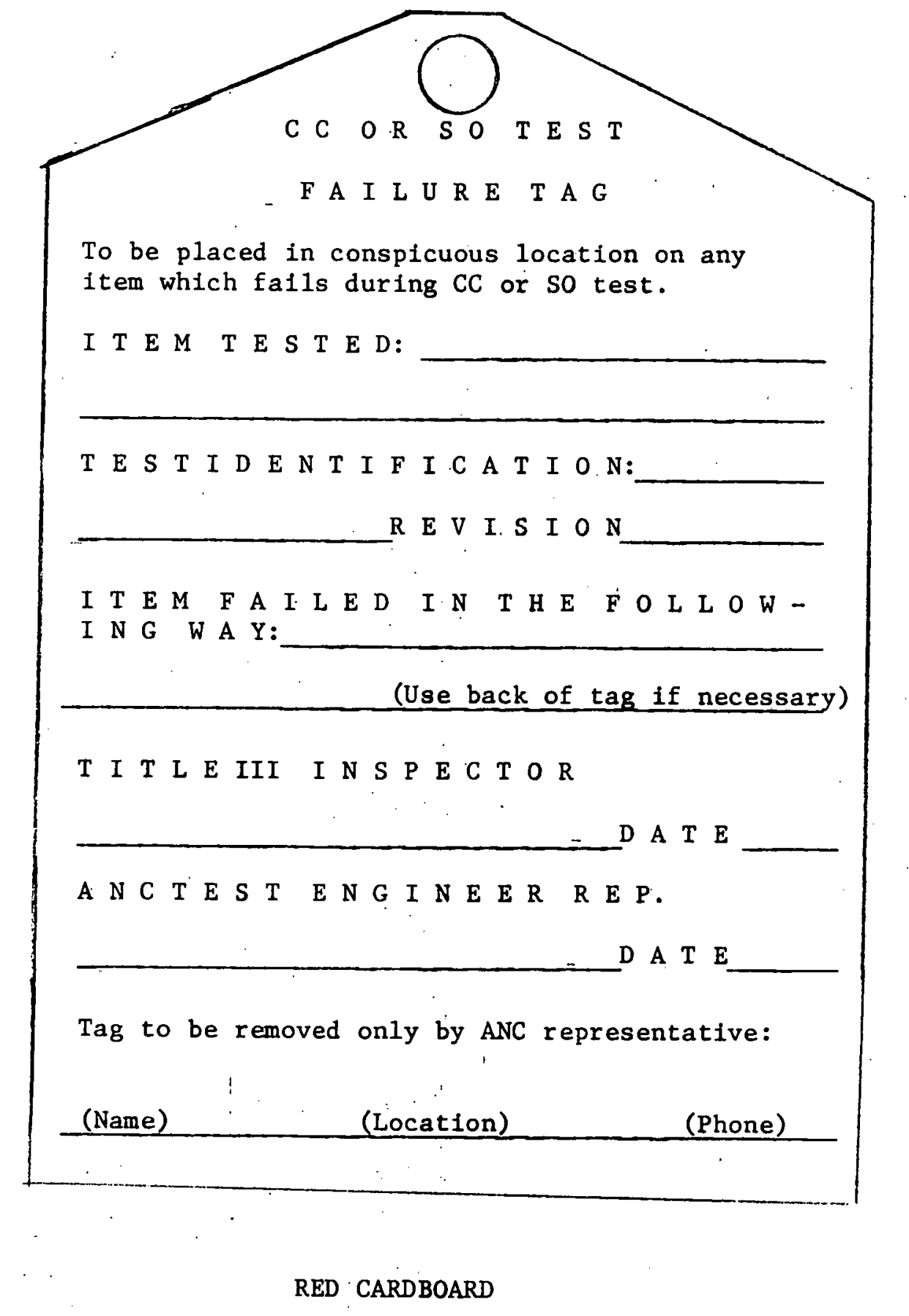

\section{Cómmon use}

To be placed near the failure, but still easily visible.

Test used and Rev. No.

This is an ANC tag. Others should not remove it. 
Valves, group of valves pump, inst., or group of instruments, tank, etc.

CC Test Revision used.

Purpose stated

Construction Contractor release permitting ANC to use \& so test.

Title III Inspector's acknowledgement of satisfaction.

ANC's acknowledgment of satisfaction.

This is an ANC tag \& others should not remove it. 


\section{RESOLUTION OF CHANGES}

OR VARIANCES TO A CC TEST

In the event test procedure must be changed or a variance occurs between the test performance and the test documentation, the ANC Test. Engineer w11l Immediately contact the appropriate $R \&$ QA personnel and the Manager, $\mathrm{PBF}$ Special Projects for resolution.

After the resolutions have been made, the ANC Test Engineer will document the change or variance and its resolution, and append the documentation to the Test Specification or Test Data Sheet, whichever the case may be. 
Aerojet Nuclear Company

PBF Project

P.O. Box 1845

Idaho Falls, Idaho 83401

Date

Subcontract No.

\section{EXCEPTIONS TO CC TEST}

CC TEST NO.

ITEM AND/OR EQUIPMENT NO.

\section{To: ANC Resident Engineer}

The following are not acceptable under this test and must be corrected before the test can be signed off as complete.

1. Description of Deficiency

2. Recommendations for Correction or Repair

\section{Distribution:}

W. E. Durkee

R. E. Heffner

B. K. Pope

A. G. McGuire

K. C. Relph

File: 01A03 
Aerojet Nuclear Company

PBF Project

P.O. Box 1845

Idaho Falls, Idaho 83401

Date

\section{Deficiency ACTION REQUEST}

CC Test No.

Item/Equipment No.

Contract No.

To: Construction Superintendent

The following corrections or repalrs are requested on CC fest No. 1.

2.

Please sign and return one (1) copy of this transmittal after the above actions have been completed.

I certify that the above deficiency actions have been completed as specified.

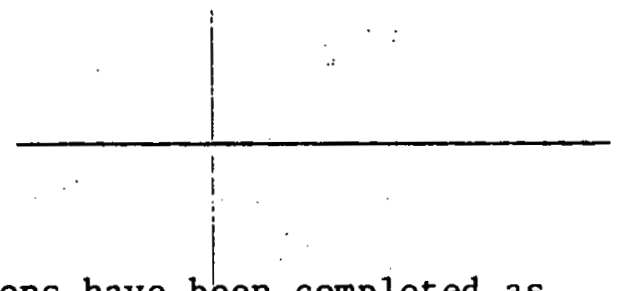

Construction Superintendent

Distribution:

W. E. Durkee

R. H. Hef fner

K. C. Relph

A. G. McGuire

B. K. Pope

R. D. M. Gildersleeve 
CC TEST NO. SUBCONTRACT NO.

ITEM AND/OR EQUIPMENT NO.

Test Supervised By:

Date

Test Witnessed By:

Test Engineer, Aerojet

Date

$R \& Q A$ Inspector

Date

Test Approved By:

\begin{tabular}{l} 
Test Engineer, ANC \\
$\begin{array}{l}\text { Manager of PBF Special Projects } \\
\text { Aerojet Nuclear Company }\end{array}$ \\
$\begin{array}{l}\text { Superintendent of PBF Shift Operations } \\
\text { Aerojet Nuclear Company }\end{array}$ \\
\hline R \& QA
\end{tabular}

This sheet accompanies final copy of approved CC Test Specification and Test Data Record Sheets 
Exhibit H

Form $\mathrm{C}-103$

\section{RECOMMENDED IMPROVEMENT LIST}

To: Manager, PBF Shift Operations

Reference: CC Test No.

The following improvements in design are recommended:

1 .

2 .

$R \& Q A$

ANC Cognizant Engineer

$c c:$ 


\section{Aerojet nuclear Company}

Interoffice Correspondence

PBF Manager Special Projects

INCOMPLETE CONNECTION CC/SO TEST NO.

The following connections were not permanent or were otherwise incomplete at the end of $\mathrm{CC}$ testing or during so testing.

1.

2.

3.

4.

These have now been permanently connected, tested and approved.

Distribution

R. E. Heffner

P. K. Pope

A. G. McGulre

K. C. Relph 
Exhibit K

Form $\mathrm{C}-105$

SO TES T WAIIVER

System or Items:

The system (or items) Identifled above, is (are) considered to have adequately met System Operation Tests under CC- Therefore, the SO test is waived.

PBF Special Projects Manager

PBF Program Manager 
